\section{A $<5$ year olds}

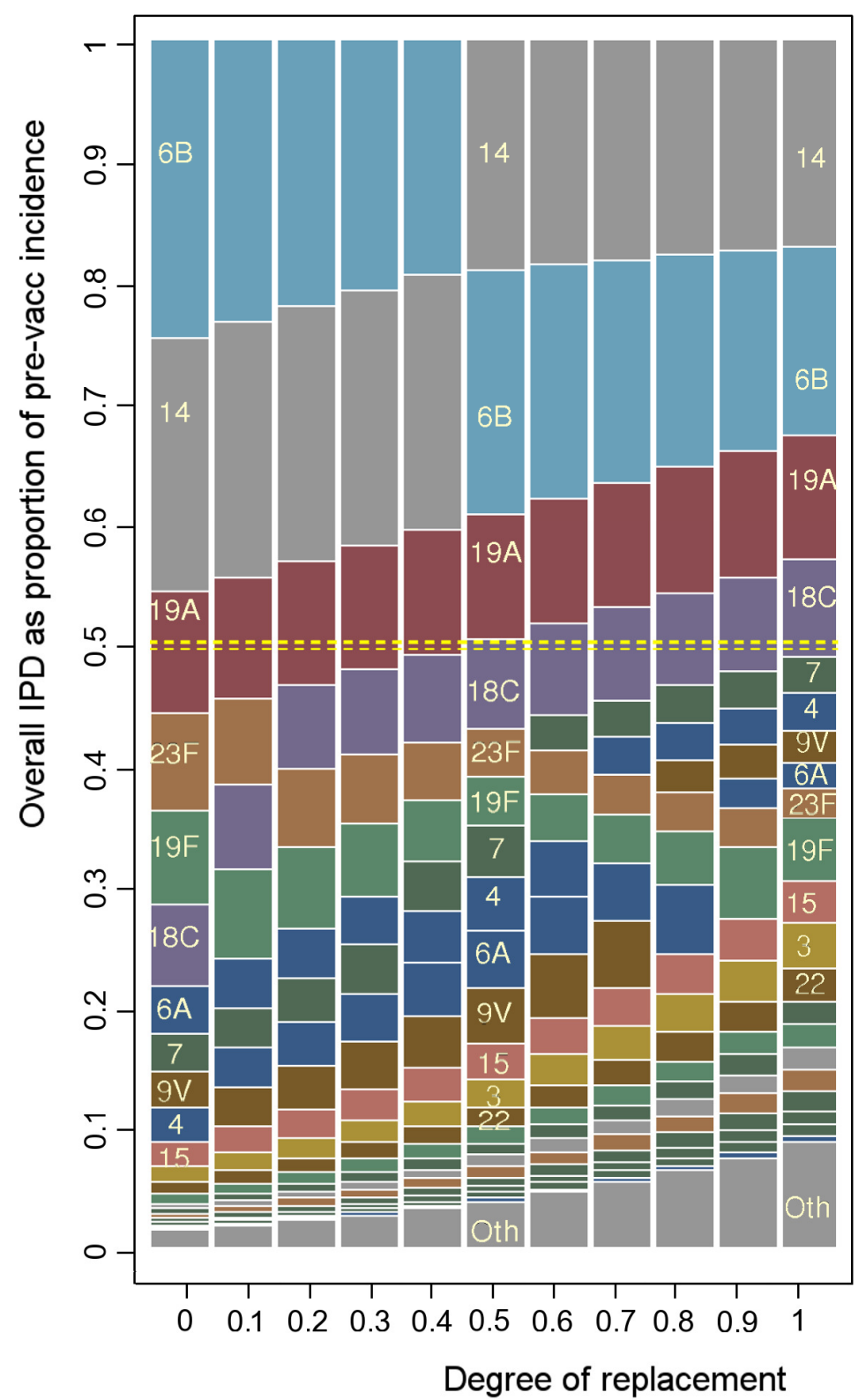

\section{B 5+ year olds}

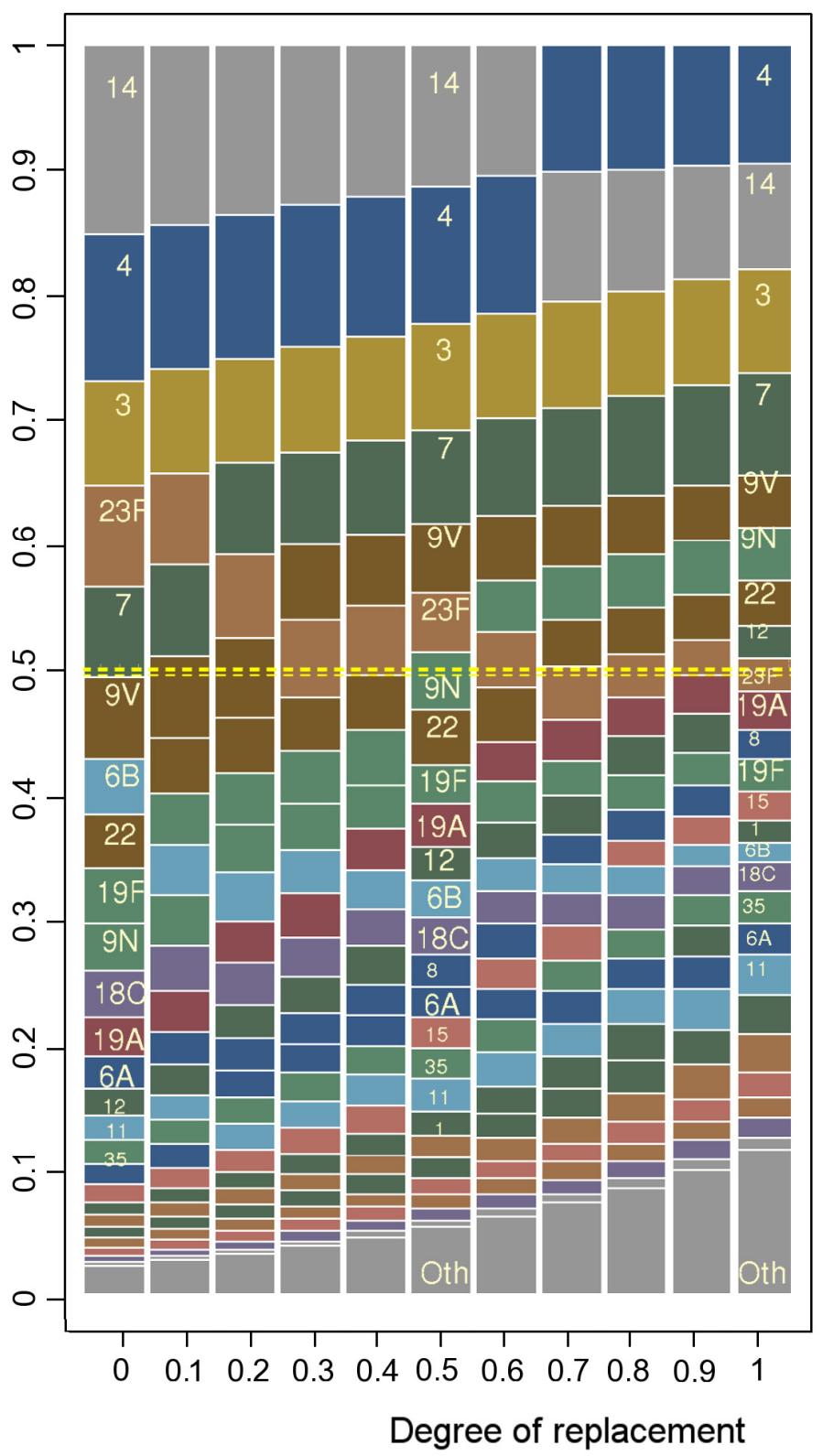

Figure S3 